\title{
Stratus optical coherence tomography finding's in patients with retinopathy of prematurity
}

\author{
Tomografia de coerência óptica em pacientes com retinopatia da prematuridade
}

\author{
Aline do Lago' ${ }^{1}$ \\ Lícia Matieli ${ }^{2}$ \\ Michele Gomes ${ }^{3}$ \\ Natalia Tamie Baba ${ }^{4}$ \\ Michel Eid Farah ${ }^{5}$ \\ Rubens Belfort Junior ${ }^{6}$ \\ Nilva Simeren Bueno de Moraes $^{7}$
}

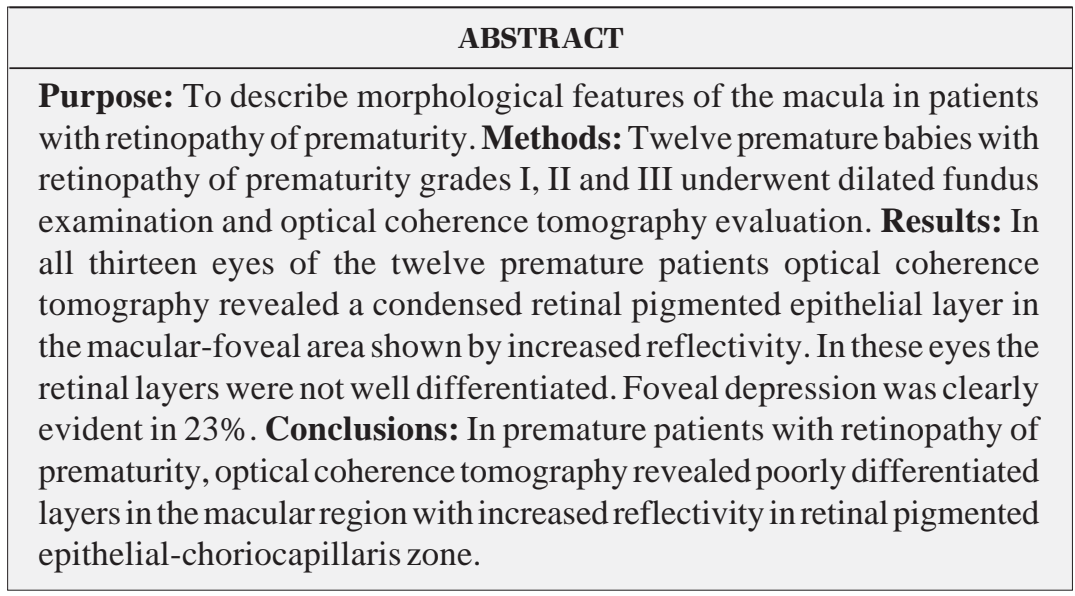

Keywords: Retinopathy of prematurity; Tomography, optical coherence; Macula lutea; Fovea centralis

\section{INTRODUCTION}

Retinopathy of prematurity (ROP) is a proliferative disease ${ }^{(1)}$ and is still a major cause of blindness in children in the developed world despite preventive strategies of screening examinations and current treatment of threshold disease ${ }^{(2)}$. Studying the premature infant shortly after birth with Stratus optical coherence tomography $(\mathrm{OCT})^{(3)}$, give us an opportunity to evaluate the macula area as it exists in utero and help us to better understand the last stages of fetal development.

Foveal maturation appears to be a slow process, although it has been considered to be the first region to undergo maturation ${ }^{(3)}$. Human macula does not complete its development until a number of weeks after birth ${ }^{(4-5)}$. Macular alterations are present only in advanced ROP, and usually consist of temporal displacement or tractional retinal detachment ${ }^{(6)}$. In ROP, the presence of a line or a ridge in the peripheral retina may act as a barrier retarding peripheral migration of cells even in the posterior pole and thus delay macula development.

In this study, our aim was to investigate the morphologic characteristics of the macula through OCT in premature patients with retinopathy of prematurity.

\section{METHODS}

Twelve patients with retinopathy of prematurity grades I, II and III were prospectively evaluated from May to October 2004 by an ophthalmic examination with indirect ophthalmoscopy. 
Screening check-ups were scheduled according to UK guidelines that recommend ophthalmologic examination in all infants of less than 1500 grams birth weight and less than 32 weeks of gestational age ${ }^{(7)}$. Informed consent was obtained from each patient's mother. Each baby was documented according to the International Classification of $\mathrm{ROP}^{(8)}$. Babies' pupils were dilated with $0.5 \%$ cyclopentolate and $2.5 \%$ phenylephrine eye drops instilled at least 30 minutes before examination. Topical anesthetic eye drops $(0.1 \%$ proxymetacaine hydrochloride) were instilled immediately before examination. A lid speculum and a scleral indenter were used to assist the positioning of the eye. After the examination, the babies were submitted to OCT evaluation. The fovea was measured four times for the 6 radial scans. Fundoscopy, classification and OCT were peformed on the same day.

\section{RESULTS}

OCT images were obtained from fourteen eyes of thirteen premature babies (Table 1). Nominal categorization of ROP was applied according to the International Classification of $\mathrm{ROP}^{(7)}$. Mean age and weight were 28 weeks and 1271.1 grams respectively (range examination at from 24 to 32 weeks and 760 to 1710 grams). Mean age was 2 months and two days. ROP I was identified in four eyes (30.7\%), ROP II in $23.1 \%$ (3/13 eyes) and six eyes had ROP III (46.2\%). Although OCT images of one patient (31 weeks, 1060 grams), were analyzed, they were not included in the final results in table 1 because the baby had no ROP.

The fovea, with its characteristic depression, was easily recognizable in the retinal profile in patient \#5 (Figure 1). OCT findings in patient \#8 revealed the photoreceptor layer as a poorly reflective band immediately above the retinal pigment epithelium and that the band was thicker in the area of the foveal depression (Figure 2). The characteristic external portion of the

\begin{tabular}{|c|c|c|c|c|}
\hline Case & $\begin{array}{l}\text { Age at } \\
\text { birth }\end{array}$ & $\begin{array}{l}\text { Weight at } \\
\text { birth }\end{array}$ & $\begin{array}{l}\text { Age at } \\
\text { exam }\end{array}$ & Eye selected ${ }^{\dagger}$ \\
\hline 1 & $24 w$ & $1030 \mathrm{~g}$ & $2 \mathrm{~m} \mathrm{2d}$ & ROP $3+Z 3$ \\
\hline 2 & $24 w$ & $1040 \mathrm{~g}$ & $2 \mathrm{~m}$ & ROP 2+ Z2 \\
\hline 3 & $28 w$ & $1590 \mathrm{~g}$ & $2 m 19 d$ & ROP 3 Z3 \\
\hline 4 & $29 w$ & $1710 \mathrm{~g}$ & $2 \mathrm{~m} 2 \mathrm{~d}$ & ROP $1 \mathrm{Z3}$ \\
\hline 5 & $29 w$ & $1490 \mathrm{~g}$ & $4 m$ & ROP 1 Z3 \\
\hline 6 & $31 w$ & $1640 \mathrm{~g}$ & $1 \mathrm{~m}$ & ROP $1 \mathrm{Z3}$ \\
\hline 7 & $32 w$ & $1620 \mathrm{~g}$ & $1 \mathrm{~m}$ & $\mathrm{ROP} 3+\mathrm{Z2}$ \\
\hline 8 & $27 w$ & $875 g$ & $3 m 15 d$ & ROP $3+$ Z2 \\
\hline 9 & $28 w$ & $1380 \mathrm{~g}$ & $1 \mathrm{~m} \mathrm{15d}$ & ROP 2 Z3 \\
\hline 10 & $27 w$ & $1210 \mathrm{~g}$ & $2 m$ & $\mathrm{ROP} 1+\mathrm{Z3}$ \\
\hline 11 & $29 w$ & $1420 \mathrm{~g}$ & $1 \mathrm{~m} \mathrm{15d}$ & ROP $2+Z 3$ \\
\hline $12^{*}$ & $27 w$ & $760 \mathrm{~g}$ & $2 m$ & ROP 3 Z2 \\
\hline
\end{tabular}

retina with its highly reflective band that corresponded to the retinal pigment epithelium and the less reflective structure which matched up with Bruch's membrane and choriocapillaris layer were also observed underneath (Figure 3). This preterm infant (31 weeks, 1060 grams), who had no ROP signals, was examined at 3 months of age and became our control.

\section{DISCUSSION}

The macula of the fetal retina is one of the last parts of the eye to complete its development ${ }^{(3)}$. OCT has an important his-

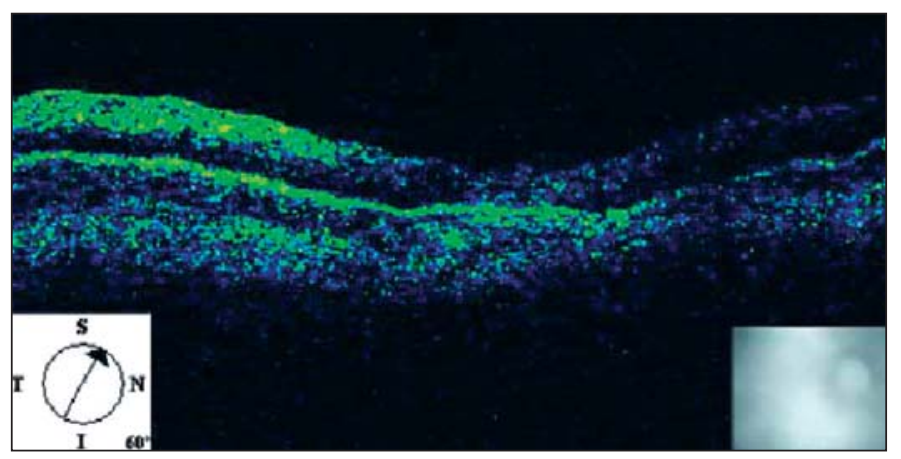

Figure 1 - Optical coherence tomography shows the foveal depression of patient \#5

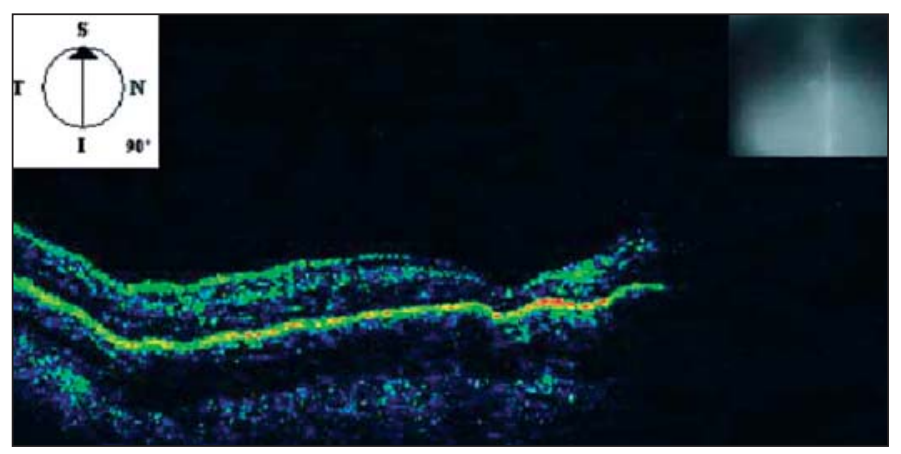

Figure 2 - Optical coherence tomography shows the poorly reflective band immediately above the retinal pigment epithelium layer (\#8)

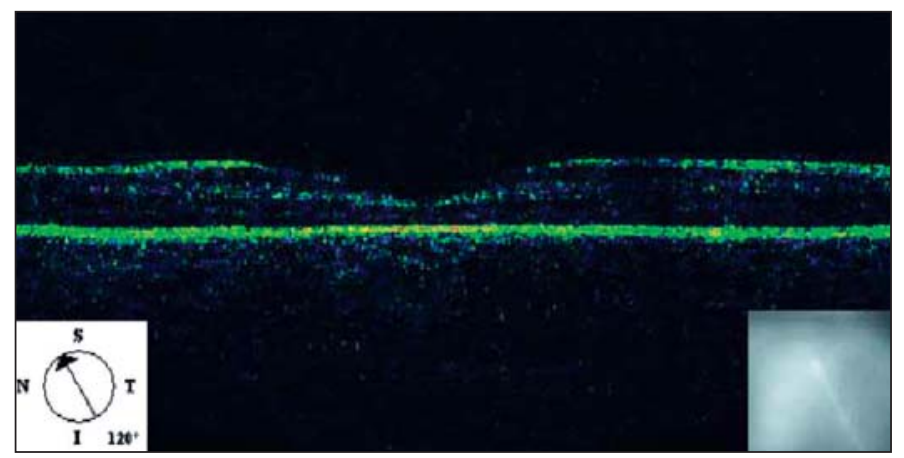

Figure 3 - Optical coherence tomography reveals a foveal depression of a normal premature baby and the hyperreflectivity of the external retina 
tological/clinical correlation with the inner parts of the retina in many diseases of the posterior segment. By studying the premature infant shortly after birth with Stratus OCT, it is possible to observe in vivo the structures of the last stages of the fetal retina ${ }^{(9)}$.

OCT allows the retina to be studied in cross-sections from the vitreous/internal limiting membrane interface to the choriocapillaris and the inner choroidal layers ${ }^{(9)}$.

Some authors observed that at 22 weeks of gestation, the fovea is a circular or elliptical zone approximately $1.5 \mathrm{~mm}$ in diameter comprising five to seven layers of cells in the ganglion cell layer, a thin nerve fiber layer, a well-defined inner plexiform, inner nuclear and outer plexiform layers and an outer nuclear layer as well containing exclusively cone nuclei ${ }^{(4)}$. The first recognizable depression in the central region of the macula is first evident at 24-26 weeks of gestation, apparently caused by thinning of the ganglion cell and inner nuclear layers. By the seventh month of gestation the inner nuclear layer becomes markedly thinned and the foveal pit appears more prominent. At 8 months two layers of ganglion cells remain; this is reduced to a single layer in the neonate. Between birth and 45 months of age the diameter of the cones continues to decrease. Fovea reaches maturity from 11 to 15 months to five years ${ }^{(7)}$.

Yuodelis and Hendrickson affirmed that the foveal pit is more pronounced at the seventh month of gestation by histological evaluation and that the macula continues its development as late as five years from birth ${ }^{(5)}$. The patients presented in table 1 had ROP disease between grades I to III according to the International Classification ${ }^{(8)}$. None of them showed macula detachment at fundoscopy or by OCT. In all cases the OCT features of the macular region had a strong correlation with the known histological aspects of the normal macula of a preterm baby, according to the literature ${ }^{(3-5)}$. Easily recognizable foveal depression and the external portion of the neural retina were found in three babies. One of them had no ROP (Figure 3). The highly reflective band that corresponded to the retinal pigment epithelium and the photoreceptor layer as well was observed in all babies.

\section{CONCLUSION}

These findings demonstrated that Stratus OCT may be a useful exam to acess the macula morphology of normal premature babies and with ROP (class I, II, III) without any interventional procedure. OCT enables the diagnosis and quantifies retinal features. It could be useful to follow the development of the macula anatomy in those patients.

We are unaware of previous reports of Stratus OCT images of premature infants with and without retinopathy of prematurity and we could find no reference to them in a computerized search using MEDLINE.

\section{RESUMO}

Objetivo: Descrever os aspectos morfológicos da mácula em pacientes com retinopatia da prematuridade (ROP). Métodos: Doze pacientes com retinopatia da prematuridade graus I, II and III foram submetidos a mapeamento de retina e avaliação por tomografia de coerência óptica. Resultados: Em todos os treze olhos de 12 pacientes a tomografia de coerência óptica mostrou a camada do epitélio pigmentar hiperrefletiva, sendo a área macular com maior intensidade. Nesses olhos as camadas da retina não estavam totalmente diferenciadas. A depressão foveal ficou claramente evidente pela tomografia de coerência óptica em 23\%. Conclusão: Nos pacientes prematuros com retinopatia da prematuridade, a tomografia de coerência óptica mostrou as camadas da retina pouco diferenciadas com aumento da refletividade na área macular do complexo epitélio retiniano pigmentar-coriocapilar.

Descritores: Retinopatia da prematuridade; Tomografia de coerência óptica; Macula lutea; Fóvea central

\section{REFERENCES}

1. Liarth JCS, Gonçalves JOR, Gonçalves EA, Meneses ES, Soares FM. Laser de diodo no tratamento da retinopatia da prematuridade. Arq Bras Oftalmol. 2001;64(5):411-3.

2. Smith LE. Pathogenesis of retinopathy of prematurity. Growth Horm IGF Res. 2004;14 Suppl A:S140-4.

3. Hendrickson A. A morphological comparison of foveal development in man and monkey. Eye. 1992;6(Pt 2):136-44.

4. Hendrickson AE, Yuodelis C. The morphological development of the human fovea. Ophthalmology. 1984;91(6):603-12.

5. Yuodelis C, Hendrickson A. A qualitative and quantitative analysis of the human fovea during development. Vision Res. 1986;26(6):847-55.

6. Isenberg SJ. Macular development in the premature infant. Am J Ophthalmol. 1986 Jan 15;101(1):74-80.

7. Retinopathy of prematurity: guidelines for screening and treatment. The report of a Joint Working Party of The Royal College of Ophthalmologists and the British Association of Perinatal Medicine. Early Hum Dev. 1996;46(3):239-58.

8. An international classification of retinopathy of prematurity. The Committee for the Classification of Retinopathy of Prematurity. Arch Ophthalmol. 1984; 102(8):1130-4.

9. Brancato R, Lumbroso B. Guide to optical coeherence tomography Interpretation. Rome: Innovation-News-Communication; 2004.

Nos artigos enviados para publicação, o nome dos autores e suas afiliações devem estar completos. Isso facilitará a indexação e os links com as bases de dados e o CV Lates. 